\title{
Ecosystem-Based Food Production: Consumers' Preferred Practices and Willingness to Buy and Pay
}

\author{
Eija Pouta *(D), Eero Liski ${ }^{(D}$, Annika Tienhaara, Kauko Koikkalainen and Antti Miettinen (D) \\ Natural Resources Institute Finland (Luke), Latokartanonkaari 9, FI-00790 Helsinki, Finland; \\ eero.liski@luke.fi (E.L.); annika.tienhaara@luke.fi (A.T.); kauko.koikkalainen@luke.fi (K.K.); \\ antti.miettinen@luke.fi (A.M.) \\ * Correspondence: eija.pouta@luke.fi; Tel.: +358-503439834
}

Citation: Pouta, E.; Liski, E.;

Tienhaara, A.; Koikkalainen, K.;

Miettinen, A. Ecosystem-Based Food Production: Consumers' Preferred Practices and Willingness to Buy and Pay. Sustainability 2021, 13, 4542. https://doi.org/10.3390/su13084542

Academic Editor: Rosa Maria Fanelli

Received: 17 March 2021

Accepted: 16 April 2021

Published: 19 April 2021

Publisher's Note: MDPI stays neutral with regard to jurisdictional claims in published maps and institutional affiliations.

Copyright: (c) 2021 by the authors. Licensee MDPI, Basel, Switzerland. This article is an open access article distributed under the terms and conditions of the Creative Commons Attribution (CC BY) license (https:// creativecommons.org/licenses/by/ $4.0 /)$.

\begin{abstract}
Ecosystem-based agricultural practices that utilize ecosystem processes aim to either reduce the negative externalities of agricultural production or increase the production of ecosystem services other than food provision. We examined consumer interest in buying and paying for food produced using ecosystem-based agricultural practices. According to the results, the most preferred practices were the more efficient use of livestock manure, the use of nitrogen-fixing crops, biological pest control, and the addition of soil carbon. Having these practices as an attribute of a food product increased the interest in buying the product for $43 \%$ of consumers. Their median willingness to pay (WTP) was $20 \%$ higher than for conventional products. Using socioeconomic and attitudinal variables, a hurdle model revealed the characteristics of a consumer segment interested in ecosystem-based agricultural practices.
\end{abstract}

Keywords: ecosystem services; contingent behavior methods; contingent valuation; consumer characteristics; organic production

\section{Introduction}

Two options to enhance agriculture that take into account the wide range of ecosystem services beyond just food are (1) the design of agri-environmental policies [1] (2) to leave the responsibility for the supply of these ecosystem services to the markets, where consumer choices reveal the demand for these services to producers [2]. These two options can also complement each other; part of the environmental concern is passed to producers via policy and part of it is passed through the demand for credence goods, such as organic foods. In this study, we focused on the possibilities of the latter option and analyzed the demand among Finnish consumers for cultivation practices that enhance ecosystem functions and reduce the negative externalities from agriculture.

The externalities of agricultural production affect the state of agricultural ecosystems and other ecosystems, such as water bodies, that, depending on their state, provide ecosystem services for humans [3,4]. Agricultural intensification may also lead to reductions in biodiversity and, consequently, negatively affect pollination by insects or biological pest control $[5,6]$. Enhancing ecosystem functions with ecosystem-based agricultural practices could solve some of these externalities, increase the supply of ecosystem services, and benefit crop production, for example by allowing a reduction in the use of synthetic fertilizers and pesticides [7].

Understanding consumer preferences for agricultural practices is important because they can provide possibilities to apply market-based approaches to solve the environmental challenges of production. Information on consumer preferences could influence agricultural practices directly or the ensemble of practices included in organic production [8,9].

In this study, we were interested in the consumer demand for agricultural practices that either reduce the external costs of agricultural production or increase the production of other ecosystem services than food. We went beyond the organic production label 
to consider actual agricultural practices. The practices we were interested in rely on enhancing ecosystem functions in crop production. We defined the characteristics for the consumer segments interested in each practice. Furthermore, we measured consumer willingness to purchase food products produced with these practices and willingness to pay for these products.

\section{Previous Literature}

It is generally foreseen that future growth in population and consumption, but also the rising role of bioenergy crops, will increase the global demand for agricultural products over the next decade [10]. Future production increases will have to come to a large extent from intensifying agriculture on existing agricultural lands [11]. The intensification is likely to cause reductions in biodiversity and a negative impact on natural resources on long run such as undesirable effects on pollination or biological pest control [12]. Understanding the dependences in the complex agricultural food systems is a necessity for the design of sustainable alternatives [13]. For example, to maintain functioning agricultural production systems, apt soil management measures are required to prevent soil degradation that could harm future agricultural production [10].

There are several terms and frameworks in literature to structure the discussion of the challenges of and solutions for producing more food at the same time as protecting natural resource base and environment. The concept of sustainable intensification (SI) recognizes the need for a productive and remunerative agriculture that also preserves and enhances ecosystem service provision [14-16]. SI for crop production has been discussed in several reviews e.g., [17-21]. According to FAO [22], SI in crop production can be achieved through good farming practices where farmers utilize knowledge of biological processes and manage ecosystems to improve productivity and sustainability of production systems. These ecosystem-based practices, refined on a local level, aim at meeting consumer needs for products that are of high quality, safe and produced in responsible way. Examples of ecosystem-based practices include conservation agriculture relying on the natural biological processes above and below the ground e.g., minimum mechanical soil disturbance and direct seeding, permanent organic soil cover, diversified crop rotations, crop-livestock systems, integrated pest management, integrated plant nutrient management, agricultural water management and pollination management.

From the point of view of consumer studies these ecosystem-based practices can be seen to produce credence goods. Credence goods [23] are most often private goods that sometimes have public good characteristics [24]. According to previous studies, consumers care about credence attributes with regards to environmental reasons as a primary driver of food purchase decisions [25-28]. However, in the previous literature, agricultural practices that enhance ecosystem functions by increasing ecosystem services and reducing negative externalities have seldom been used as a quality argument for credence goods as such. Typically, these characteristics are hidden behind labels, such as organic production.

Organic food has gained popularity and experienced steady growth over recent decades [29]. Organic crop production has clear criteria, but the combination of agricultural practices behind organic production has seldom been opened up in consumer studies. There has been criticism towards the content of organic production from the environmental point of view, as the environmental impacts per unit of production have been higher in organic than in conventional production [30-32]. As it is expensive for producers to follow all the criteria of organic production, it has been suggested that the agricultural practices of organic production could be selectively implemented and the products promoted as grown using ecological practices rather than being certified as organic [33].

Previous studies have demonstrated that if the demand for individual agricultural practices is examined separately, they are valued differently compared to the combination of practices labeled as organic [34]. For example, 'organic' production is more far-reaching than the pesticide-free attribute, since, among other restrictions, no synthetic pesticides can be used in organic production. However, the organic attribute has been found to be 
less significant in the buying decision [34]. Previous literature on organic production has defined a segment of consumers that is interested in purchasing as well as a segment that is willing to pay for organic goods. The demand for organic foods has been examined and summarized in a meta-analysis of 33 studies [35] focusing on willingness to pay (WTP) for the organic attribute of a good. The analysis revealed that WTP is below $20 \%$ for half of consumers but female gender and household size are positively related to the demand for organic goods. The association with age has been described as an inverse U-shape.

The separate agricultural practices comprising organic production or environmentally friendly production have been tested from the viewpoint of consumer preferences in a small number of studies [26,33,36-39]. Typically, such studies have only focused on a single practice, which in most cases has been that related to pest management.

Khachatryan and Rihn [38] demonstrated that the plant type under cultivation influences the perceived importance of agricultural practices regarding pollination. For food crop plants, the practice 'grown without pesticides' was perceived as the best one for pollinator health, whereas the practice 'grown outside' was ranked the highest for landscape plants. The 'grown using synthetic pesticides' practice was ranked the least beneficial method by consumers, regardless of the plant type. Maples et al. [33] included a wider selection of agricultural practices in their evaluation as credence attributes for tomatoes. They found that consumers were willing to pay more for tomatoes grown using less water, containing lower levels of pesticide residues, grown with organic fertilizers, or transported over shorter distances to the final point of sale. Moser, Raffaelli and ThilmanyMcFadden [34] reviewed previous results concerning fruits and vegetables produced with integrated pest management, showing that consumers who have previous knowledge of this topic are willing to pay a premium of six percent or higher $[36,40]$.

In the following, we focus on the consumer preferences for ecosystem-based crop production practices. Our study questions are: (1) what are the practices that interest consumers, (2) how many consumers are interested to buy food produced with these practices and (3) how much they are willing to pay for it. Furthermore, (4) we are interested to reveal those socio-demographic variables that significantly associate with willingness to buy and pay for food produced with ecosystem-based practices.

Finnish consumers are well suited to examine these study questions as approximately $80 \%$ of the food consumed in Finland is also produced there. The share of domestic products is especially high in grain products, as on a typical year, the national production covers the consumption [41]. In addition, there is a need to develop organic production in Finland [42] with a potential to increase the share of consumed organic products ( $€ 50 /$ person compared to $€ 60$ /person average in Europe [43] while the share of active users of organic foods was $32 \%$ [44]. Understanding consumers' preferences towards different agricultural practices facilitates developing an organic label and helps to improve the desirability of organic food.

\section{Data and Methods}

\subsection{Applied Methods}

To identify the consumer preferences for agricultural practices that reduce negative externalities or produce more ecosystem services, we applied three methods (Figure 1).

First, we identified a selection of ecosystem-based agricultural practices that target externalities and ecosystem service provision. These practices needed to be well known and understandable for a layperson, and also feasible from the farmers' point of view. The nine selected practices were tested in stakeholder discussion with participants from the administration and NGOs $(N=6)$. The practices were further tested in a pilot survey $(\mathrm{N}=202)$ and accepted for the final survey. In the final survey, we used the self-explicated approach (SEA) to define preferences for these ecosystem-based agricultural practices. SEA refers to a class of preference measurement approaches in which respondents directly evaluate the desirability of each attribute level, as well as the importance of the attributes $[45,46]$. In our case, the SEA consisted of one task where the respondents selected two to five attributes, i.e., agricultural practices, that they would like to have implemented for a food product. 
With this approach, we avoided difficulty in ranking all the attributes and problems related to rating, i.e., the typical phenomenon of finding all the attributes to be important.

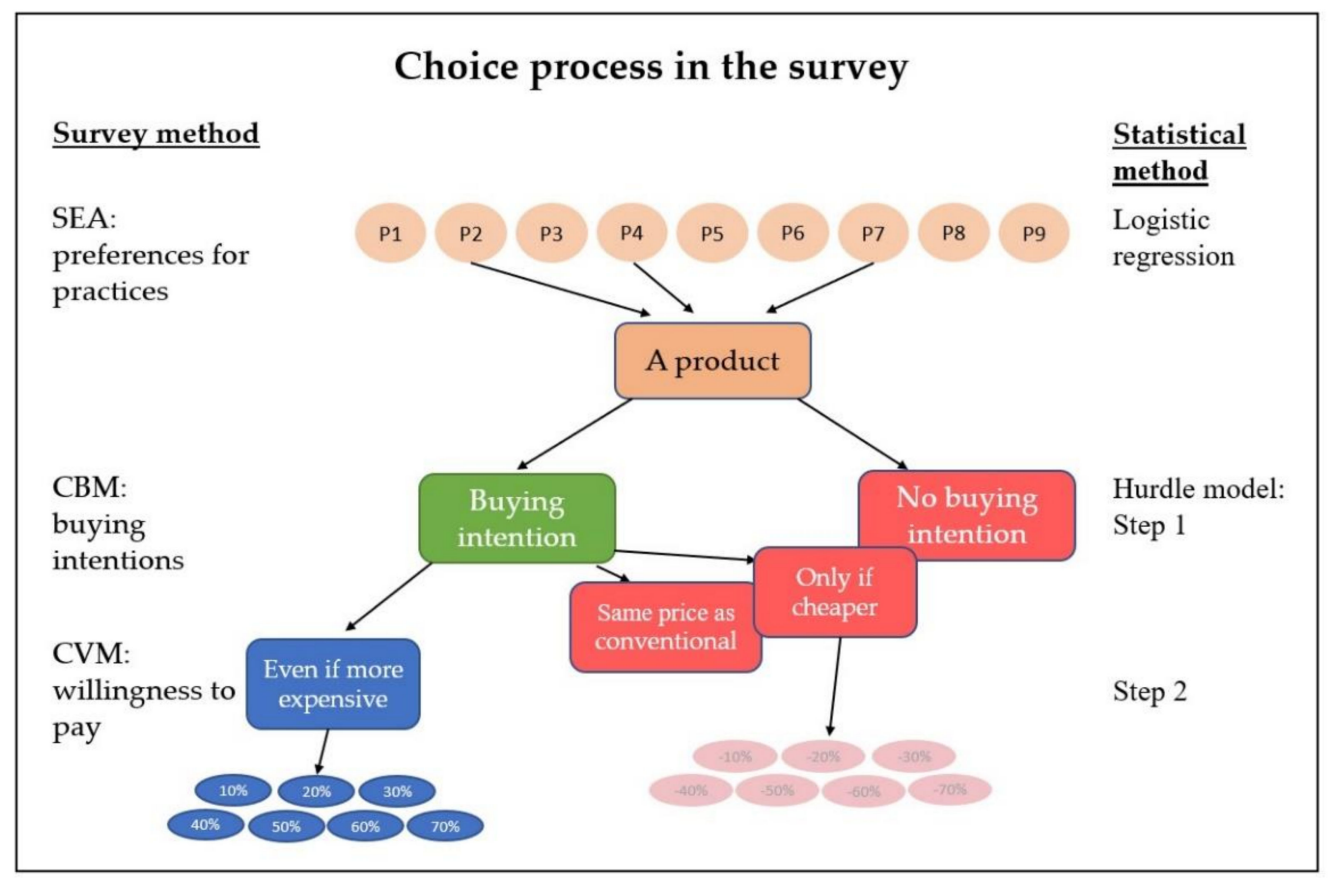

Figure 1. The correspondence between survey methods, the respondent's choice process and the statistical methods.

Since the possibilities to buy food products that limit externalities from agriculture and enhance ecosystem functions in Finland are restricted to organic products, purchasing behavior could not be examined in actual markets. Therefore, we secondly focused on consumers' buying intentions, which can be examined with the contingent behavior method (CBM). In the CBM, people are asked how they would behave in a particular new situation, for example if food products that enhance ecosystem functions were available. The method has earlier been used in the context of food purchasing. Previous examples of surveying buying intentions have included products such as organic, ethnic, or genetically modified food, agricultural genetic resources, and food labeling [47-50].

Third, the value of goods that are not available on the market can be examined with stated preference methods, such as the contingent valuation method (CVM) or a choice experiment [51]. Here, we selected the CVM, as for the number of attributes we included, a choice experiment would have been demanding to implement. A choice experiment was also impossible because of the respondent burden, as the survey already included an agri-environmental policy-related choice experiment [48]. In the CVM, which is typically applied in the environmental valuation of non-market goods, respondents are asked about their willingness to pay (WTP) for a specific good or service. Common elicitation formats include, for example, open ended question, payment card and single or double bounded dichotomous choice [52]. The effect of various factors on WTP can also be modeled. Applications related to agricultural products are less common in the literature [53]. Recently, however, the contingent valuation method has been more frequently used to measure consumer preferences for new products [54] and to determine the factors influencing the WTP for food products [50,55]. A discrepancy between hypothetical and actual payments, i.e., the hypothetical bias, is possible in WTP. The premiums elicited in an actual buying context have been found to be significantly lower than hypothetical premiums [56]. However, in the case of a new product that does not exist on the market, the hypothetical setting is the only feasible option to examine the demand. Beyond the average willingness to pay for a product, it is important to identify the consumer segments that are interested in the prod- 
uct and to define how different variables, such as consumer attitudes or socio-economic characteristics, influence the willingness to pay.

\subsection{Data Collection}

Survey data on ecosystem services from agricultural environments were collected using an Internet survey during the spring of 2016. The sample was drawn from the Internet panel of a private survey company, Taloustutkimus, which comprised 30,000 respondents who had been recruited to the panel using random sampling to represent the population [57]. After a pilot survey of 202 people, a random sample of 8391 respondents was selected, of whom 2066 completed the survey. This corresponds to a response rate of $25 \%$. Based on the socio-demographic variables, the sample represented the Finnish population rather well.

\subsection{Survey Questions}

The survey first introduced the respondents to some basic facts concerning agriculture and related environmental issues. After questions concerning the perceived importance of ecosystem services and perceptions concerning the possibilities to provide them with agri-environmental policies, the survey contained a set of questions about using ecosystem processes to reduce externalities and enhance ecosystem services. The presented agricultural practices (9) were targeted at the following externalities and ecosystem services: soil fertility, pest and weed control, clean water/water purification, climate regulation, and maintaining natural diversity. The items included in the list are presented in Table 1. Three of these practices are required in the current conditions for organic production. Four of the practices are not required in organic production, but two of these are regularly applied and two occasionally in the present cultivation practices for organic production.

The next part of the survey focused on taking ecosystem functions into account in agricultural practices. First, respondents were presented with the following information: "There are several alternative ways to produce food. One of these alternatives is to enhance nature's own functions on fields to reduce the environmental effects of agriculture. Enhancing natural functions could provide benefits, for example, by allowing a reduction in synthetic fertilization and the use of pesticides." The respondents were then presented a list of agricultural practices of this kind in food production (Table 1).

Respondents were asked to select from two to five agricultural practices they would like to see implemented in food production (Figure 1). Thus, the selected practices defined the characteristics of food production in the CB and CV questions. In the CB question, the selected agricultural practices were defined as follows: "If the agricultural practices were used in food production as certified and this type of food was available, I would buy it: (a) only if it was cheaper than conventional food; (b) if the price was same as that of conventional food; (c) even if it was more expensive than conventional food; or (d) I would not choose this type of food."

Contingent valuation was implemented to include both positive and negative directions and a payment card approach was used as an elicitation format. If alternative A was chosen in the CB question, a respondent was asked how much cheaper this type of food should be compared to conventional food so that the respondent would buy it. The scale ranged from $10 \%$ to $70 \%$, with $10 \%$ increments, also including the "I don't know" response. If alternative $\mathrm{C}$ was chosen, the respondent was asked how much more expensive this type of food could be at maximum compared to conventional food. Again, the scale ranged from $10 \%$ to $70 \%$, with $10 \%$ increments, and the "I don't know" response was included. Percentages were used instead of euros as the product type was not specified.

After the CV questions, respondents were asked to provide background information. 
Table 1. The agricultural practices from which respondents were asked to select two to five options they would prefer to be implemented in food production.

\begin{tabular}{|c|c|c|}
\hline Agricultural Practices in the Survey & Variable & $\begin{array}{l}\text { Relation to Organic } \\
\text { Production }\end{array}$ \\
\hline $\begin{array}{l}\text { More efficient use of livestock } \\
\text { manure instead of synthetic fertilizers } \\
\text { in order to maintain land fertility }\end{array}$ & Livestock manure & In present conditions \\
\hline $\begin{array}{l}\text { Use of nitrogen-fixing crops, such as } \\
\text { clover and peas, as a complement to } \\
\text { synthetic fertilization }\end{array}$ & Nitrogen-fixers & In present conditions \\
\hline $\begin{array}{l}\text { Cultivation of mixtures of cereal } \\
\text { crops to reduce the risk of pests and } \\
\text { diseases and achieve a higher } \\
\text { crop yield }\end{array}$ & Mixtures of cereal & Used regularly \\
\hline $\begin{array}{l}\text { Use of ground preparation to reduce } \\
\text { the use of herbicides }\end{array}$ & Less herbicides & Used regularly \\
\hline $\begin{array}{l}\text { Use of biological control (e.g., insects, } \\
\text { birds) for pests instead of } \\
\text { chemical control }\end{array}$ & Bio-control & Used regularly \\
\hline $\begin{array}{l}\text { Sowing without ploughing (direct } \\
\text { sowing) to reduce nutrient emissions } \\
\text { and maintain soil fertility }\end{array}$ & Direct sowing & Used occasionally \\
\hline $\begin{array}{l}\text { Site-adapted use of fertilizers to } \\
\text { enhance the protection of waters }\end{array}$ & Adapt fertilizer & Used regularly \\
\hline $\begin{array}{l}\text { Addition of plant-based } \\
\text { (carbon-containing) material to soil to } \\
\text { mitigate climate change }\end{array}$ & Soil carbon add & Used occasionally \\
\hline $\begin{array}{l}\text { Uncultivated diversity strips on the } \\
\text { edges of the fields to diversify natural } \\
\text { habitats (plants, birds, insects, } \\
\text { small mammals) }\end{array}$ & Diversity strips & In present conditions \\
\hline
\end{tabular}

\subsection{Statistical Analyses}

We assumed that consumers have preferences for agricultural practices. These practices can be expected to increase consumer interest in buying the product and also increased the WTP for it. We assumed that consumers simultaneously make the buying decision and the willingness to pay decision for the product that complies with their preferred agricultural practices. We also assumed that the socioeconomic background, such as income, and attitudes of consumers influence their preferences for practices, as well as their willingness to buy and WTP. Furthermore, we analyzed whether the choice of agricultural practices is associated with interest in buying and WTP.

After descriptive analysis of the three dependent variables, statistical models were constructed. The modelling approach is presented in Figure 1. The selection of agricultural practices was explained with a logistic regression model. The responses for practices were classified as "Yes" for a person if any of the choices ( 2 to 5 choices) included the specific agricultural practice. Otherwise, the response was defined as "No". This logic was applied to each of the nine agricultural practices. Each practice response was modeled separately. We used 10-fold cross-validation to find the predictor set with the best prediction accuracy. For each model, we calculated prediction accuracies for each predictor combination. When the predictor set with the maximum accuracy was identified, the model was fitted using this final predictor set for the whole data.

The purchase decision and the WTP decision were modeled with a two-tier hurdle model [58]. As a first step (Hurdle 1), the overall willingness to buy measured with the CB question was modeled, and as a second step (Hurdle 2), the willingness to pay derived 
from the CV question was modeled. For Hurdle 1, the response was classified as "Yes" if a person was interested in buying food "even with a higher price" in the chosen basket consisting of 2-5 agricultural practices. Otherwise, the response was defined as "No". We applied a logistic regression model to the whole set of potential predictors in Hurdle 1. In interval regression of Hurdle 2, we applied a parametric survival model of the form $T \sim \beta^{T}$ $+\sigma \varepsilon$, where $\varepsilon \sim N(0,1)$ and $\sigma$ denotes the scale. $T$ takes values of $(0, \infty)$, and its distribution is specified by a cumulative distribution function (in our case normal). The best set of predictors was found by separately maximizing the prediction accuracy for Hurdle 1 and Hurdle 2. Descriptive information on the predictors is presented in Table 2.

Table 2. Independent variables in the models.

\begin{tabular}{cc}
\hline Variable & Distribution (Categoricals) \\
\hline Importance: biodiversity & 0.49 \\
(ref. average or low) & 0.37 \\
Importance: landscape & 0.49 \\
Importance: climate & 0.68 \\
Importance: waters & 0.09 \\
Education (ref. elementary) & 0.22 \\
Vocational & 0.10 \\
High school & 0.20 \\
College & 0.11 \\
University & 0.27 \\
Farmer & 0.02 \\
Farmland owner & 0.15 \\
Gender female (ref. male) & 0.45 \\
Age $<34$ years & 0.13 \\
Lives in rural area & 0.25 \\
East or north Finland & 0.23 \\
Nature conservationist & 0.11 \\
under $€ 500$ & 0.03 \\
$€ 500-999$ & 0.02 \\
$€ 1000-1499$ & 0.07 \\
$€ 1500-1999$ & 0.10 \\
$€ 2000-2999$ & 0.13 \\
$€ 3000-3999$ & 0.28 \\
$€ 4000-4999$ & 0.19 \\
$€ 5000-6999$ & 0.08 \\
over $€ 7000$ & 0.06 \\
Monthly income: no income (ref. no income) & 0.02 \\
\hline
\end{tabular}

First, the hurdle model was fitted as a general model without adding information on the selected agricultural practices. Second, each practice was modeled separately with its own two-tier hurdle model. A model was separately fitted for each practice by adding a dummy variable (1) if a specific ecosystem service was chosen as a predictor (0 otherwise). In total, 9 models were fitted for the hurdle model.

\section{Results}

The descriptive results from the data indicate the preferences for various agricultural practices to enhance ecosystem services and reduce negative externalities. Table 3 presents the most frequently selected practices. These were related to the more efficient use of livestock manure instead of synthetic fertilizers, the use of nitrogen-fixing plants, the addition of soil carbon, and biological pest control (see Table 1 for detailed practices). The most preferred practices were thus associated with many ecosystem services, including water quality control, biodiversity, and climate regulation. No single ecosystem service had a dominant status among the preferred practices of the respondents. 
Table 3. Proportion of respondents who selected each agricultural practice.

\begin{tabular}{cc}
\hline Variable & \% of Sample \\
\hline Soil carbon add & 58 \\
Livestock manure & 57 \\
Nitrogen fixers & 55 \\
Bio-control & 50 \\
Diversity strips & 42 \\
Less herbicides & 33 \\
Direct sowing & 24 \\
Adapt fertilizer & 24 \\
Mixture of cereals & 17 \\
\hline
\end{tabular}

Table 4 reveals the willingness to buy and pay figures for a product in which the agricultural practices enhance natural functions on fields to reduce the environmental effects of agriculture. Altogether, $43 \%$ of the respondents were interested in buying the product, even if it was more expensive than a conventional product. According to the WTP distribution, the median WTP was $20 \%$ higher than for conventional food. Bids of over $40 \%$ were made by less than one-tenth of all the respondents.

Table 4. Willingness to buy and pay for a product produced with selected agricultural practices.

\begin{tabular}{cc}
\hline & Proportion of Respondents, $\%$ \\
\hline Willingness to buy & \\
\hline Only if cheaper & 54 \\
If the same price & 43 \\
Even if more expensive & \\
\hline Willingness to pay more & 34 \\
\hline $10 \%$ & 43 \\
$20 \%$ & 16 \\
$30 \%$ & 2 \\
$40 \%$ & 2 \\
$50 \%$ & 1 \\
$60 \%$ & 1 \\
$70 \%$ & 0 \\
$80 \%$ & 0 \\
$90 \%$ & 1 \\
$100 \%$ &
\end{tabular}

The logistic regression models for selecting each agricultural practice are presented in Table 5. The environmental attitudes show consistency in how various practices are associated with attitudes towards the externalities of agriculture: biodiversity, landscape, climate regulation, and water quality. Agricultural practices that were selected by those who perceived biodiversity as an important target were nitrogen fixers, using mechanical management instead of herbicides, biological pest control, direct sowing, and diversity strips. Landscape targets were associated with a preference for the application of livestock manure. This is understandable, as seeing livestock in the landscape has been one of the most important landscape attributes in previous studies [59]. The importance of climate targets was associated with selection of the soil carbon amendment practice. Those who considered water quality important also preferred biological pest control and the site-adapted use of fertilizers. 
Table 5. Preference for agricultural practices $\left({ }^{* * *} p<0.01,{ }^{* *} p<0.05, * p<0.1\right)$.

\begin{tabular}{|c|c|c|c|c|c|c|c|c|c|c|c|c|c|c|c|c|c|c|}
\hline \multirow[b]{2}{*}{ Intercept } & \multicolumn{2}{|c|}{$\begin{array}{c}\text { Livestock } \\
\text { Manure }\end{array}$} & \multicolumn{2}{|c|}{ Nitrogen Fixers } & \multicolumn{2}{|c|}{$\begin{array}{l}\text { Mixture of } \\
\text { Cereals }\end{array}$} & \multicolumn{2}{|c|}{$\begin{array}{c}\text { Preparation, } \\
\text { Lower Herbicide } \\
\text { Use }\end{array}$} & \multicolumn{2}{|c|}{$\begin{array}{c}\text { Biological Pest } \\
\text { Control }\end{array}$} & \multicolumn{2}{|c|}{ Direct Sowing } & \multicolumn{2}{|c|}{$\begin{array}{l}\text { Site-Adapted } \\
\text { Use of Fertilizers }\end{array}$} & \multicolumn{2}{|c|}{$\begin{array}{l}\text { Addition of Soil } \\
\text { Carbon }\end{array}$} & \multicolumn{2}{|c|}{ Diversity Trips } \\
\hline & 0.741 & $* *$ & -0.202 & * & -1.755 & $* * *$ & -1.346 & $* * *$ & 0.089 & & -1.599 & $* * *$ & 0.456 & ** & -1.952 & $* * *$ & -0.757 & $* * *$ \\
\hline Importance: biodiversity & & & 0.331 & * & 0.007 & & 0.2580 & $* *$ & 0.469 & $* * *$ & 0.267 & $* *$ & -0.384 & $* * *$ & 0.122 & & 0.940 & $* * *$ \\
\hline Importance: landscape & 0.515 & $* * *$ & & & -0.086 & & & & & & -0.242 & $* *$ & & & -0.229 & * & -0.065 & \\
\hline Importance: climate & & & & & 0.285 & $*$ & 0.073 & & & & & & 0.024 & & 0.509 & $* * *$ & & \\
\hline Importance: waters & -0.125 & & & & -0.422 & $* * *$ & & & 0.442 & $* * *$ & & & 0.549 & $* * *$ & & & & \\
\hline Education (ref. elementary) & & & & & & & & & & & & & & & & & & \\
\hline . Vocational & -0.261 & & -0.033 & & 0.701 & $* * *$ & -0.336 & * & & & 0.296 & & 0.005 & & 0.331 & & & \\
\hline · College & -0.297 & & 0.111 & & 0.410 & & -0.474 & $* * *$ & & & 0.150 & & 0.107 & & 0.458 & * & & \\
\hline $\begin{array}{c}\text { · University } \\
\text { (applied sciences) }\end{array}$ & -0.309 & & 0.071 & & 0.488 & & -0.746 & $* * *$ & & & 0.339 & & -0.373 & $*$ & 0.401 & & & \\
\hline University & -0.598 & $* * *$ & 0.386 & $* *$ & 0.447 & $*$ & -0.657 & $* * *$ & & & 0.231 & & 0.291 & & 0.264 & & & \\
\hline Farmer & -0.037 & & & & & & & & & & -0.728 & * & -0.436 & & 0.789 & ** & & \\
\hline Farmland owner & -0.097 & & 0.245 & * & 0.241 & & & & -0.195 & & 0.252 & & & & -0.611 & $* * *$ & & \\
\hline Gender female (ref. male) & & & 0.028 & & 0.143 & & 0.215 & $* *$ & 0.104 & & -0.244 & $* *$ & & & & & & \\
\hline Age $<34$ years & & & & & & & 0.849 & $* * *$ & 0.002 & & & & -0.327 & ** & -0.329 & * & & \\
\hline Lives in a rural area & 0.031 & & 0.464 & $* * *$ & -0.291 & $*$ & & & -0.231 & $* *$ & 0.466 & $* * *$ & -0.124 & & & & & \\
\hline East or north Finland & 0.275 & $* *$ & & & -0.004 & & 0.358 & $* * *$ & & & -0.460 & $* * *$ & 0.049 & & 0.198 & & -0.173 & \\
\hline Nature conservationist & 0.168 & & & & -0.265 & & 0.141 & & 0.469 & $* * *$ & & & -0.476 & $* * *$ & 0.163 & & 0.522 & $* * *$ \\
\hline . under $€ 500$ & -0.413 & & & & 0.532 & & & & -0.840 & $* *$ & -0.394 & & & & 0.725 & & & \\
\hline · 500-999 & 0.009 & & & & -0.044 & & & & -0.392 & & 0.160 & & & & 0.480 & & & \\
\hline . $€ 1000-1499$ & -0.273 & & & & -0.092 & & & & -0.786 & $* *$ & 0.336 & & & & 0.382 & & & \\
\hline . $€ 1500-1999$ & -0.265 & & & & -0.537 & & & & -0.362 & & 0.358 & & & & 0.508 & & & \\
\hline . $€ 2000-2999$ & -0.182 & & & & -0.207 & & & & -0.575 & ** & 0.288 & & & & 0.382 & & & \\
\hline · $€ 3000-3999$ & -0.437 & & & & -0.079 & & & & -0.612 & $* *$ & -0.119 & & & & 0.423 & & & \\
\hline . $€ 4000-4999$ & -0.217 & & & & -0.337 & & & & -1.044 & $* * *$ & 0.251 & & & & 0.524 & & & \\
\hline . $€ 5000-6999$ & -0.615 & & & & 0.408 & & & & -0.803 & $* *$ & 0.359 & & & & 0.695 & * & & \\
\hline . over $€ 7000$ & -0.180 & & & & 0.131 & & & & -0.748 & $*$ & 0.521 & & & & 1.032 & $* *$ & & \\
\hline No information rate & 0.572 & & 0.560 & & 0.826 & & 0.667 & & 0.505 & & 0.763 & & 0.585 & & 0.770 & & 0.572 & \\
\hline Cross-validation accuracy & 0.592 & & 0.590 & & 0.826 & & 0.673 & & 0.610 & & 0.764 & & 0.605 & & 0.771 & & 0.627 & \\
\hline LR test $p$-value & $<0.01$ & & $<0.01$ & & $<0.05$ & & $<0.01$ & & $<0.01$ & & $<0.01$ & & $<0.01$ & & $<0.01$ & & $<0.01$ & \\
\hline Nagelkerke $R^{2}$ & 0.045 & & 0.033 & & 0.032 & & 0.047 & & 0.077 & & 0.042 & & 0.047 & & 0.044 & & 0.083 & \\
\hline Hosmer-Lemeshow GOF test & $>0.05$ & & $>0.05$ & & $>0.05$ & & $>0.05$ & & $>0.05$ & & $>0.05$ & & $>0.05$ & & $>0.05$ & & $>0.05$ & \\
\hline
\end{tabular}


The choices of farmers and farmland owners differed significantly from those of the other respondents regarding certain practices. Farmers particularly supported the addition of soil carbon, whereas farmland owners supported plants that contribute to nitrogen fixation. Female and younger respondents especially preferred soil preparation to avoid the use of herbicides. Residence in a rural area was associated with the agricultural practices of cultivating nitrogen fixers and direct sowing. Regional differences were also found, as respondents from the eastern and northern parts of Finland supported livestock manure and the reduced use of herbicides. These preferences were associated with animal husbandry in these areas. A small group of respondents belonging to nature conservation organizations had some special characteristics in their preferences, as they supported biological pest control and biodiversity strips, agricultural practices that are especially related to biodiversity. The preference for biological pest control was stronger among those with the lowest income level.

To summarize the results for interest in buying and WTP, we first present the hurdle models without defining the chosen agricultural practices (Table 6). Second, we summarize how the nine practices affected the two steps of the hurdle model (Table 7) if included in the model one by one. The interest in buying a food product produced with the selected practices was significantly and positively associated with environmental attitudes, especially those towards biodiversity and water quality. From the socio-demographic background variables, a university degree, being a farmer, living in the east or north of Finland, and belonging to a nature conservation organization increased the interest in buying. A higher WTP was only significantly associated with nature conservationists and farmers.

Table 6. Hurdle model for the interest in buying and WTP with no agricultural practices included in the model $\left({ }^{* * *} p<0.01,{ }^{* *} p<0.05\right)$.

\begin{tabular}{|c|c|c|c|c|}
\hline \multirow[b]{2}{*}{ Constant } & \multicolumn{2}{|c|}{$\begin{array}{l}\text { Step } 1 \\
\quad \text { Logistic Regression }\end{array}$} & \multicolumn{2}{|c|}{$\begin{array}{l}\text { Step } 2 \\
\text { Interval Regression }\end{array}$} \\
\hline & -1.106 & $* * *$ & 1.503 & $* * *$ \\
\hline Importance of biodiversity & 0.565 & $* * *$ & 0.053 & \\
\hline $\begin{array}{c}\text { Importance of water effects } \\
\text { Education }\end{array}$ & 0.334 & $* * *$ & -0.024 & \\
\hline Vocational school & 0.068 & & 0.040 & \\
\hline High school & -0.026 & & 0.206 & \\
\hline College & 0.113 & & -0.252 & \\
\hline University (applied sciences) & 0.431 & $* *$ & -0.102 & \\
\hline University & 0.419 & $* *$ & 0.053 & \\
\hline Farmer & 0.631 & $* *$ & 0.945 & $* * *$ \\
\hline East or north Finland & 0.273 & $* *$ & -0.070 & \\
\hline Nature conservationist & 0.696 & $* * *$ & 0.443 & $* * *$ \\
\hline $\log$ (scale) & & & 0.236 & \\
\hline No information rate & 0.561 & & 0.430 & \\
\hline Cross-validation accuracy & 0.611 & & 0.431 & \\
\hline LR test $p$-value & $<0.01$ & & $<0.01$ & \\
\hline Concordance index & 0.638 & & & \\
\hline Nagelkerke $R^{2}$ & 0.078 & & & \\
\hline Hosmer-Lemeshow GOF test & $>0.05$ & & & \\
\hline
\end{tabular}

Table 7 reveals those agricultural practices that, if included in the hurdle model, increase the interest in buying and WTP. The effect on buying interest was highest for biological pest control, but the use of livestock manure, nitrogen fixers, and diversity strips also increased the interest in buying. WTP only significantly increased in the models for nitrogen fixers and the site-adapted use of fertilizers. 
Table 7. Effects of agricultural practices in hurdle models if included one by one.

\begin{tabular}{ccccc}
\hline & \multicolumn{2}{c}{ Step 1 } & \multicolumn{2}{c}{ Step 2 } \\
& Bogistic Regression & \multicolumn{2}{c}{ Interval Regression } \\
& B & Sig & B & Sig \\
\hline Livestock & 0.237 & $* *$ & & $*$ \\
manure & 0.213 & $* *$ & & $*$ \\
Nitrogen fixers & 0.408 & $* * *$ & 0.197 & \\
Bio-control & & $* *$ & & \\
Adapt fertilizer & 0.240 & & & \\
Diversity strips & & &
\end{tabular}

\section{Discussion and Conclusions}

The results of this study can be concluded as follows. Consumers are interested in agricultural production practices that reduce negative externalities and increase the provision of ecosystem services. The respondents were especially interested in soil management practices and practices improving biodiversity. The agricultural practices increased the willingness to buy, as $43 \%$ of respondents were interested in buying the product if produced by applying their selected practices, even if it was more expensive than conventional food products, and the median WTP was $20 \%$ higher than for conventional food.

Compared to the majority of previous studies that have focused on organic production practices as an entity, the strength of our analysis is that we allowed consumers to evaluate the ecosystem based practices separately instead of clustering the practices together under the organic label. Thus, our results are comparable to those few previous studies on consumer preferences that have differentiated agricultural practices, and some similarities were found. In a study by Maples et al. [33], soil-related practices, especially organic fertilizers, were emphasized. In our case, from among the agricultural practices, the use of nitrogen fixers especially increased the willingness to pay. Similarly to our results of high preferences for biological pest control, Maples et al. [33] observed that products containing lower levels of pesticide residues were preferred. In our results, the agricultural practice that increased the buying intention the most was the use of biological pest control.

The WTP for foods produced with the favored agricultural practices was on the level of the price premium for organic products if compared to previous international studies. In the meta-analysis of Xia and Zeng [35], the WTP for the organic attribute of a food product was around $20 \%$. Compared to consumers' interest in buying organic products in Finland, the results here indicated slightly lower interest (luomu.fi). The median price premium of $20 \%$ was also lower than the actual price premium of organic grain products in Finland. However, compared to the price premium of $6 \%$ for a single agricultural practice reported in Moser, Raffaelli, and Thilmany-McFadden [34], the combination of two to five practices that consumers selected had a higher price premium, as could be expected.

In our study, we aimed at expressing the agricultural practices in such a way that a layperson could understand them. Nevertheless, with our survey-based method, we could not be sure whether the respondents were familiar with all the practices we introduced or guarantee that the respondents would be fully aware of the meaning and the impacts of all the proposed agricultural practices. Awareness of the methods most probably relates to the higher interest among nature conservationists and farmers in buying the products and paying for them. This is in line with the finding of Govindasamy and Italia [36] and Cranfield and Magnusson [40] that previous knowledge of the topic increases the price premium.

We defined the characteristics of the segment of consumers interested in practices enhancing ecosystem functioning. Having a high intention to buy was more easily profiled than having a high willingness to pay. Unlike studies on organic production, we did not find a positive relationship between a respondent's female gender or age and buying intentions [35]. In our case, a high level of education, residence in the east or north of 
Finland, and being a farmer or nature conservationist increased the demand. Furthermore, positive attitudes toward ecosystem services and low externalities from agricultural lands increased the demand. These results provide some information for producers to assist them in finding the segment of interested consumers, as well as an opportunity to differentiate their products from other products based on the production methods used. As no ready label exists for these production methods, local markets that facilitate close communication between consumers and producers are possible alternatives to reach interested consumers.

One possible weakness of our study was that mimicking the consumer decision process in a survey was rather inflexible. In our approach, three decisions were made by the consumers, one after another, concerning the choice of preferred practices, interest in buying, and WTP. We assumed that the choice of the practices was made separately but, in reality, all the three choices would most probably be made simultaneously. Integrating the decision would, however, considerably complicate the statistical analysis. Therefore, in our case only two of the decisions, buying and paying, were integrated in modelling, and the choice of practices was analyzed separately.

As our focus went beyond the organic production label to actual agricultural practices, our results are applicable in the development of organic production if there is interest in revising the conditions of organic production. According to the results, three out of the five agricultural practices most preferred by the consumers are currently part of the requirements in organic production. However, the results demonstrated how organic conditions may be extended to better correspond to consumer expectations: soil carbon amendment, which is not part of the current requirements, was a practice that interested consumers. In addition, the use of biological pest control was appealing to consumers, and even though it is used in vegetable production, it could also have a stronger role in other organic plant production.

From the agricultural practices regularly or occasionally used in organic production, ground preparation reducing the use of herbicides and direct sowing are practices that cause especially high expenses for farmers and thus partly limit their shift to organic production. However, according to the results of this study, they may not be particularly important to consumers. It would be very interesting in future research to focus on some of the agricultural practices and compare in more detail the results for consumer demand with information on the production costs for farmers.

These empirical results of consumer preferences for various production methods also has importance for international processes of developing criteria for organic production, although more empirical studies on consumer preferences are needed from other countries. Following the approach of our study, but focusing on regionally relevant agricultural practices, would widen the knowledge base of defining organic practices. Together with information on the environmental effects of various production methods, this would lead to more science-based development of the content of organic production.

The study generated ideas to continue research in the future. New empirical studies from different regions and other management practices are needed. The focus of this study was on plant production. However, revealing the preferences for environmentally friendly animal production and measuring consumer interest in buying and willingness to pay would be an interesting topic for future studies. Furthermore, more studies are needed concerning consumers' awareness of management practices. In a survey research the assumption is that consumers can process very concise information on production methods. Involving consumers more in depth in planning the management practices in real life food production processes would reveal new aspects concerning their knowledge and preferences.

Author Contributions: Conceptualization, E.P., K.K. and A.M.; formal analysis, E.L.; funding acquisition, E.P.; investigation, K.K. and A.M.; methodology, E.L.; project administration, E.P.; software, E.L.; writing—original draft, E.P., E.L. and A.T.; writing—review \& editing, E.P., A.T., K.K. and A.M. All authors have read and agreed to the published version of the manuscript. 
Funding: This research was funded by the Academy of Finland [310205] and The Development Fund for Agriculture and Forestry (MAKERA) by the Finnish Ministry of Agriculture and Forestry [1798/312/2014].

Institutional Review Board Statement: Not applicable.

Informed Consent Statement: Informed consent was obtained from all subjects involved in the study.

Data Availability Statement: Data available from authors.

Conflicts of Interest: The authors declare no conflict of interest. The funders had no role in the design of the study; in the collection, analyses, or interpretation of data; in the writing of the manuscript, or in the decision to publish the results.

\section{References}

1. Batáry, P.; Dicks, L.V.; Kleijn, D.; Sutherland, W.J. The role of agri-environment schemes in conservation and environmental management. Conserv. Biol. 2015, 29, 1006-1016. [CrossRef]

2. Green Consumerism: Perspectives, Sustainability, and Behavior; Malyan, R.S.; Duhan, P. (Eds.) Apple Academic Press: Waretown, NJ, USA, 2018; p. 410.

3. Rojas, L.T.; Regmi, A.; Kleinwechter, U. Literature Review on the Integration of Ecosystem Services in Agricultural Economic Models. Impact Assessment Discussion Paper 14. Biodiversity International 2015. Available online: https: //www.bioversityinternational.org/e-library/publications/detail/literature-review-on-the-integration-of-ecosystemservices-in-agricultural-economic-models / (accessed on 28 March 2021).

4. Weltin, M.; Zasada, I.; Piorr, A.; Debolini, M.; Geniaux, G.; Perez, O.M.; Scherer, L.; Marco, L.T.; Schulp, C.J. Conceptualising fields of action for sustainable intensification-A systematic literature review and application to regional case studies. Agric. Ecosyst. Environ. 2018, 257, 68-80. [CrossRef]

5. Pe'Er, G.; Dicks, L.V.; Visconti, P.; Arlettaz, R.; Baldi, A.; Benton, T.G.; Collins, S.; Dieterich, M.; Gregory, R.D.; Hartig, F.; et al. EU agricultural reform fails on biodiversity. Science 2014, 344, 1090-1092. [CrossRef]

6. Gomiero, T. Effects of agricultural activities on biodiversity and ecosystems: Organic versus conventional farming. In Handbook on the Globalisation of Agriculture; Edward Elgar Publishing: Cheltenham, UK, 2015; pp. 77-105.

7. Bernard, B.; Lux, A. How to feed the world sustainably: An overview of the discourse on agroecology and sustainable intensification. Reg. Environ. Chang. 2017, 17, 1279-1290. [CrossRef]

8. Campbell, B.L.; Khachatryan, H.; Behe, B.K.; Dennis, J.; Hall, C. U.S. and Canadian Consumer Perception of Local and Organic Terminology. Int. Food Agribus. Manag. Rev. 2014, 17, 21-40.

9. Rihn, A.; Khachatryan, H.; Campbell, B.; Hall, C.; Behe, B. Consumer preferences for organic production methods and origin promotions on ornamental plants: Evidence from eye-tracking experiments. Agric. Econ. 2016, 47, 599-608. [CrossRef]

10. Levers, C.; Butsic, V.; Verburg, P.H.; Müller, D.; Kuemmerle, T. Drivers of changes in agricultural intensity in Europe. Land Use Policy 2016, 58, 380-393. [CrossRef]

11. Fanelli, R.M. The interactions between the structure of the food supply and the impact of livestock production on the environment. A multivariate analysis for understanding the differences and the analogies across European Union countries. Qual. Access Success 2018, 19, 131-139.

12. Fanelli, R.M. The Spatial and Temporal Variability of the Effects of Agricultural Practices on the Environment. Environments 2020, 7, 33. [CrossRef]

13. Peano, C.; Tecco, N.; Dansero, E.; Girgenti, V.; Sottile, F. Evaluating the Sustainability in Complex Agri-Food Systems: The SAEMETH Framework. Sustainability 2015, 7, 6721-6741. [CrossRef]

14. Conway, G. The Doubly Green Revolution: Food for All in the Twenty-First Century; Comstock Publishing Associates: Ithaca, NY, USA, 1997; 352p.

15. Godfray, H.C.J.; Garnett, T. Food security and sustainable intensification. Philos. Trans. R. Soc. B Biol. Sci. 2014, $369,20120273$. [CrossRef] [PubMed]

16. Kuyper, T.W.; Struik, P.C. Epilogue: Global food security, rhetoric, and the sustainable intensification debate. Curr. Opin. Environ. Sustain. 2014, 8, 71-79. [CrossRef]

17. Franks, J.R. Sustainable intensification: A UK perspective. Food Policy 2014, 47, 71-80. [CrossRef]

18. Pisante, M.; Stagnari, F.; Grant, C.A. Agricultural innovations for sustainable crop production intensification. Ital. J. Agron. 2012, 7, e40. [CrossRef]

19. Kassam, A.; Fridrich, R.; Shaxson, F.; Reeves, R.; Pretty, J.; de Moraes, C.; Sá, J. Production systems for sustainable intensi-fication. Schwerpkt. Tech. 2011, 20, 38-45.

20. Rockström, J.; Williams, J.; Daily, G.; Noble, A.; Matthews, N.; Gordon, L.; Wetterstrand, H.; DeClerck, F.; Shah, M.; Steduto, P.; et al. Sustainable intensification of agriculture for human prosperity and global sustainability. Ambio 2017, 46, 4-17. [CrossRef]

21. Rocchi, L.; Boggia, A.; Paolotti, L. Sustainable Agricultural Systems: A Bibliometrics Analysis of Ecological Modernization Approach. Sustainability 2020, 12, 9635. [CrossRef] 
22. FAO. An Ecosystem Approach to Sustainable Crop Production Intensification: A Conceptual Framework. 2010. Available online: http://www.fao.org/fileadmin/templates/agphome/scpi/SCPI_Compendium/SCPIConceptual_framework.pdf (accessed on 28 March 2021).

23. Wirth, F.F.; Stanton, J.L.; Wiley, J.B. The Relative Importance of Search versus Credence Product Attributes: Organic and Locally Grown. Agric. Resour. Econ. Rev. 2011, 40, 48-62. [CrossRef]

24. Lusk, J.L.; Nilsson, T.; Foster, K. Public Preferences and Private Choices: Effect of Altruism and Free Riding on Demand for Environmentally Certified Pork. Environ. Resour. Econ. 2006, 36, 499-521. [CrossRef]

25. Lusk, J.L.; Briggeman, B.C. Food Values. Am. J. Agric. Econ. 2009, 91, 184-196. [CrossRef]

26. Moser, R.; Raffaelli, R. Consumer preferences for sustainable production methods in apple purchasing behaviour: A nonhypothetical choice experiment. Int. J. Consum. Stud. 2012, 36, 141-148. [CrossRef]

27. Onken, K.A.; Bernard, J.C.; Pesek, J.D. Comparing Willingness to Pay for Organic, Natural, Locally Grown, and State Marketing Program Promoted Foods in the Mid-Atlantic Region. Agric. Resour. Econ. Rev. 2011, 40, 33-47. [CrossRef]

28. Tobler, C.; Visschers, V.H.; Siegrist, M. Eating green. Consumers' willingness to adopt ecological food consumption behaviors. Appetite 2011, 57, 674-682. [CrossRef]

29. The World of Organic Agriculture. Statistics and Emerging Trends 2019; Willer, H., Lernoud, J., Eds.; Research Institute of Organic Agriculture (FiBL): Frick, Switzerland, 2019; 351p.

30. Kirchmann, H.; Bergström, L.; Kätterer, T.; Mattsson, L.; Gesslein, S. Comparison of Long-Term Organic and Conventional Crop-Livestock Systems on a Previously Nutrient-Depleted Soil in Sweden. Agron. J. 2007, 99, 960-972. [CrossRef]

31. Leifeld, J. How sustainable is organic farming? Agric. Ecosyst. Environ. 2012, 150, 121-122. [CrossRef]

32. Shennan, C.; Krupnik, T.J.; Baird, G.; Cohen, H.; Forbush, K.; Lovell, R.J.; Olimpi, E.M. Organic and Conventional Agriculture: A Useful Framing? Annu. Rev. Environ. Resour. 2017, 42, 317-346. [CrossRef]

33. Maples, M.; Interis, M.G.; Morgan, K.L.; Harri, A. SOUTHEASTERN CONSUMERS' WILLINGNESS TO PAY FOR ENVIRONMENTAL PRODUCTION ATTRIBUTES OF FRESH TOMATOES. J. Agric. Appl. Econ. 2017, 50, 27-47. [CrossRef]

34. Moser, R.; Raffaelli, R.; Thilmany-McFadden, D. Consumer Preferences for Fruit and Vegetables with Credence-Based Attributes: A review. Int. Food Agribus. Manag. Rev. 2011, 14, 121-142.

35. Xia, W.; Zeng, Y. Consumer's Willingness to Pay for Organic Food in the Perspective of Meta-Analysis. SSRN Electron. J. 2007. [CrossRef]

36. Govindasamy, R.; Italia, J. A willingness-to-purchase comparison of integrated pest management and conventional produce. Agribusiness 1998, 14, 403-414. [CrossRef]

37. Scarpa, R.; Thiene, M.; Marangon, F. Using Flexible Taste Distributions to Value Collective Reputation for Environmentally Friendly Production Methods. Can. J. Agric. Econ. Can. D'agroeconomie 2008, 56, 145-162. [CrossRef]

38. Khachatryan, H.; Rihn, A. Consumer Perceptions of Plant Production Practices that Aid Pollinator Insects' Health. HortScience 2017, 52, 749-755. [CrossRef]

39. Tait, P.; Saunders, C.; Dalziel, P.; Rutherford, P.; Driver, T.; Guenther, M. Estimating wine consumer preferences for sustainability attributes: A discrete choice experiment of Californian Sauvignon blanc purchasers. J. Clean. Prod. 2019, 233, 412-420. [CrossRef]

40. Cranfield, J.A.L.; Magnusson, E. Canadian Consumer's Willingness-To-Pay for Pesticide Free Food Products: An Ordered Probit Analysis. Int. Food Agribus. Manag. Rev. 2003, 6, 13-30.

41. Available online: https://www.luke.fi/en/news/finnish-cereal-production-covers-domestic-consumption/ (accessed on 28 March 2021).

42. Koivisto, A.; Koikkalainen, K.; Kokkinen, M.; Jaakkonen, A.-K.; Partala, A. Tuplasti luomua: Millä keinoilla luomu-tuotteiden määrä saadaan kaksinkertaistettua nykyisellä luomupinta-alalla? Luonnonvara- ja biotalouden tutkimus 2020, 19, 40.

43. Piipponen, J.; Rinta-Kiikka, S.; Arovuori, K. Elintarvikkeiden kulutus Suomessa. PTT Työpapereita 2018, 195, 1-56.

44. ProLuomu. 2019. Available online: https://proluomu.fi/wp-content/uploads/2018/03/luomu-suomessa-2019_final.pdf (accessed on 28 March 2021).

45. Scholz, S.W.; Meissner, M.; Decker, R. Measuring Consumer Preferences for Complex Products: A Compositional Approach Based on Paired Comparisons. J. Mark. Res. 2010, 47, 685-698. [CrossRef]

46. Almli, V.L.; Øvrum, A.; Hersleth, M.; Almøy, T.; Næs, T. Investigating individual preferences in rating and ranking conjoint experiments. A case study on semi-hard cheese. Food Qual. Prefer. 2015, 39, 28-39. [CrossRef]

47. Bredahl, L. Determinants of Consumer Attitudes and Purchase Intentions with Regard to Genetically Modified Food-Results of a Cross-National Survey. J. Consum. Policy 2001, 24, 23-61. [CrossRef]

48. Tarkiainen, A.; Sundqvist, S. Subjective norms, attitudes and intentions of Finnish consumers in buying organic food. Br. Food J. 2005, 107, 808-822. [CrossRef]

49. Puduri, V.S.; Govindasamy, R. Asian Consumers' Willingness to Buy Locally Grown Ethnic Produce: A Study from East-coast United States. J. Sustain. Agric. 2011, 35, 511-521. [CrossRef]

50. Tienhaara, A.; Ahtiainen, H.; Pouta, E. Consumers as Conservers-Could Consumers' Interest in a Specialty Product Help to Preserve Endangered Finncattle? Agroecol. Sustain. Food Syst. 2013, 37, 1017-1039. [CrossRef]

51. Bateman, I.J.; Carson, R.T.; Day, B.; Hanemann, W.M.; Hanley, N.; Hett, T.; Jones-Lee, M.; Loomes, G.; Mourato, S.; Özdemiroglu, E.; et al. Economic Valuation with Stated Preference Techniques: A Manual; Edward Elgar Publishing Limited: Cheltenham, UK, 2002; 458p. 
52. Tienhaara, A.; Haltia, E.; Pouta, E.; Arovuori, K.; Grammatikopoulou, I.; Miettinen, A.; Koikkalainen, K.; Ahtiainen, H.; Artell, J. Demand and supply of agricultural ecosystem services: Towards benefit-based policy. Eur. Rev. Agric. Econ. 2020, 47, 1223-1249. [CrossRef]

53. Lusk, J.L.; Hudson, D. Willingness-to-Pay Estimates and Their Relevance to Agribusiness Decision Making. Rev. Agric. Econ. 2004, 26, 152-169. [CrossRef]

54. Carpio, C.E.; Isengildina-Massa, O. Consumer willingness to pay for locally grown products: The case of South Carolina. Agribusiness 2009, 25, 412-426. [CrossRef]

55. Banyte, J.; Brazioniene, L.; Gadeikiene, A. Investigation of green consumer profile: A case of Lithuanian market of eco-friendly food products. Econ. Manag. 2010, 15, 374-383.

56. Lusk, J.L.; Schroeder, T.C. Are Choice Experiments Incentive Compatible? A Test with Quality Differentiated Beef Steaks. Am. J. Agric. Econ. 2004, 86, 467-482. [CrossRef]

57. Taloustutkimus. Internet panel. Available online: http://www.taloustutkimus.fi/in-english/products_services/internet_panel/ (accessed on 25 January 2019).

58. Wooldridge, J.M. Econometric Analysis of Cross Section and Panel Data; MIT Press: Cambridge, MA, USA, 2010.

59. Grammatikopoulou, I.; Pouta, E.; Salmiovirta, M.; Soini, K. Heterogeneous preferences for agricultural landscape improvements in southern Finland. Landsc. Urban Plan. 2012, 107, 181-191. [CrossRef] 